\title{
Parallel Systems
}





\section{Parallel Systems}

Redundancy in Government

Jonathan B. Bendor

UNIVERSITY OF CALIFORNIA PRESS

Berkeley - Los Angeles - London 
University of California Press

Berkeley and Los Angeles, California

University of California Press, Ltd.

London, England

(C) 1985 by The Regents of the University of California

Printed in the United States of America

$\begin{array}{lllllllll}1 & 2 & 3 & 4 & 5 & 6 & 7 & 8 & 9\end{array}$

Library of Congress Cataloging in Publication Data

Bendor, Jonathan B.

Parallel Systems

Bibliography: $p$.

Includes index.

1. Public administration. 2. Organizational effectiveness. 3. Performance. 4. Reliability. I. Title. 


\section{For my parents}

Benami Bendor Learning was joyful in their home

Ruth Brodie Bendor 
